\title{
Removal of Chromium(VI) from Contaminated Water Using Untreated Moringa Leaves as Biosorbent
}

\author{
Chandra Mouli R. Madhuranthakam ${ }^{1, *}$, Archana Thomas ${ }^{1}$, Zhainab Akhter ${ }^{1}$, Shannon Q. Fernandes ${ }^{1}$ \\ and Ali Elkamel ${ }^{2}$ \\ 1 Chemical Engineering Department, Abu Dhabi University, P.O. Box 59911, Abu Dhabi, United Arab Emirates; \\ 1057074@studentsaduac.onmicrosoft.com (A.T.); 1059192@studentsaduac.onmicrosoft.com (Z.A.); \\ 1060947@studentsaduac.onmicrosoft.com (S.Q.F.) \\ 2 Chemical Engineering Department, University of Waterloo, Waterloo, ON N2L 3G1, Canada; \\ aelkamel@uwaterloo.ca \\ * Correspondence: chandra.mouli@adu.ac.ae; Tel.: +971-2-501-5304
}

Citation: Madhuranthakam, C.M.R.; Thomas, A.; Akhter, Z.; Fernandes, S.Q.; Elkamel, A. Removal of Chromium(VI) from Contaminated Water Using Untreated Moringa Leaves as Biosorbent. Pollutants 2021, 1, 51-64. https://doi.org/10.3390/ pollutants1010005

Received: 3 February 2021

Accepted: 15 February 2021

Published: 25 February 2021

Publisher's Note: MDPI stays neutral with regard to jurisdictional claims in published maps and institutional affiliations.

Copyright: (c) 2021 by the authors. Licensee MDPI, Basel, Switzerland. This article is an open access article distributed under the terms and conditions of the Creative Commons Attribution (CC BY) license (https:/ / creativecommons.org/licenses/by/ $4.0 /)$.

\begin{abstract}
Biosorption of chromium ( $\mathrm{Cr}(\mathrm{VI}))$ is studied by using raw (chemically not modified) Moringa (Moringa Oleifera) leaf powder without any pretreatment. $\mathrm{Cr}(\mathrm{VI})$ is one of the potentially harmful heavy metals found in industrial wastewater. In the Moringa leaf powder, the presence of a significant amount of organic acids form the source for the biosorption of $\mathrm{Cr}(\mathrm{VI})$. The concentration of $\mathrm{Cr}(\mathrm{VI})$ in the feed solution is varied and different dosages of the proposed biosorbent are used to study its efficiency in the removal of $\mathrm{Cr}(\mathrm{VI})$. The concentration of $\mathrm{Cr}(\mathrm{VI})$ is varied from $1 \mathrm{ppm}$ to $20 \mathrm{ppm}$ while the amount of biosorbent is varied from $0.5 \mathrm{~g}$ to $2.5 \mathrm{~g}$. The equilibrium time for adsorption of $\mathrm{Cr}(\mathrm{VI})$ is observed to vary between half an hour and $90 \mathrm{~min}$. The metal removal efficiency varied from $30 \%$ to $90 \%$ which is a significant achievement compared to other conventional methods which are either energy-intensive or not cost effective. The experimental results are modeled using Langmuir, Freundlich and Redlich-Peterson isotherms. The metal removal efficiency is attributed to the chelating effect of carboxylate and hydroxyl groups present in the moringa leaves and is confirmed from the FTIR analysis. Further molecular docking simulations are performed to confirm the binding of the metal to the speculated sites within the different acids present in the moringa leaves. Untreated green moringa leaf powder used as a biosorbent in this study leads to a sustainable and cheaper option for treating wastewater containing $\mathrm{Cr}(\mathrm{VI})$.
\end{abstract}

Keywords: biosorption; chromium removal; moringa; adsorption isotherms; molecular docking

\section{Introduction}

Heavy metals such as lead, nickel, copper, chromium, cadmium and strontium are commonly found in industrial wastewater [1]. These are hazardous and pose environmental concerns if not removed before the wastewater is discarded to the environment. This article focusses on the removal of hexavalent chromium using a biosorbent. Chromium is mainly found in the wastewater produced from the leather tanning, textile, electroplating, metal processing and chromium salt industries though there are other type of industries (such as dyeing, ceramic manufacture, mining, etc.) which also release this toxic metal into its wastewater [1]. Most of the heavy metals exist at different oxidation states and chromium exists in $\mathrm{Cr}^{3+}(\mathrm{Cr}(\mathrm{III}))$ and $\mathrm{Cr}^{6+}(\mathrm{Cr}(\mathrm{VI}))$ states in aqueous media. Among these two states, the hexavalent chromium is more harmful and toxic compared to the trivalent chromium because of its higher mobility and solubility. Studies have shown that the compounds containing hexavalent chromium are carcinogenic and can also act as mutagens [2,3]. According to the World Health Organization (WHO), the maximum allowable chromium in industrial wastewater and potable water is $0.05 \mathrm{ppm}$ and $0.1 \mathrm{ppm}$, respectively. For corresponding allowable chromium levels in other countries or regions please refer to Kinuthi et al. [4]. There are several studies and methods used to remove 
heavy metals from wastes generated from different processes. These methods vary in general based on the type of the source from which this heavy metal-associated waste is produced and also on the separation efficiency required to meet the required limits. The several common methods used for removal of chromium include chemical precipitation, ion exchange, reverse osmosis, electro dialysis and ultrafiltration [5-10]. Though all these methods can give a high metal separation efficiency their usage is restricted due to some of the serious drawbacks such as higher operational and maintenance cost, residual metal sludge treatment and/or disposal problem and in some cases incomplete metal removal. An alternate cost-effective technique for heavy metal removal from wastewater is to use adsorption method. This has led to explore different types of adsorbents that can be used to efficiently remove $\mathrm{Cr}(\mathrm{VI})$ from the waste containing this metal. Several adsorbents such as metal oxides, activated carbon and alumina, chemically modified resins and biosorbents have been developed in the past few decades [11-19]. Biosorbents form an attractive option for handling the $\mathrm{Cr}(\mathrm{VI})$ removal as they are cheaper, with less maintenance and operational cost and a higher metal separation can be achieved. There are several biosorbents that are developed to separate $\mathrm{Cr}(\mathrm{VI})$ and these include mango kernels, peanut hull, banana peels, sugarcane bagasse, sugarcane leaves, Aloe vera leaves, neem leaves, coconut shell [20]. Most of these biosorbents are modified or activated using acids to generate the metal capturing sites on the surface of the adsorbent [21,22] which improves the capability of binding the metal to the adsorption site. In our research we use raw moringa leaf powder without any activation or pretreatment with chemicals as a biosorbent to adsorb $\mathrm{Cr}(\mathrm{VI})$ from the wastewater containing this metal.

Moringa leaves come from the tree called Moringa oleifera which is commonly referred to as drumstick tree or horse radish tree. Various parts of this tree have been used for medicinal as well as a vegetable in many parts of Asia and Africa. Extensive research studies have been conducted on its medicinal, biological and physiological activities [23-26]. With respect to using the different parts of this tree for the removal of heavy metals, Reddy et al. [27] reported using its bark for the adsorption, Alves and Coelho [28] reported using its husks for removal of chromium, Obuseng et al. [29] used its seeds for removal of most of the heavy metals except chromium, and its leaves are used to remove lead by Reddy et al. [30]. Most of these studies involved chemical pretreatment of the corresponding parts of the tree before using them as an adsorbent. In our research we use raw organic moringa leaf powder for the removal of $\mathrm{Cr}(\mathrm{VI})$ and the reason for choosing this adsorbent comes from the fact that its leaves have a significant amount of ascorbic and amino acids which would enhance the binding capability of the metal to it. The powder used in this research is obtained from Organic India ${ }^{\mathrm{TM}}$ which reported that $450 \mathrm{mg}$ of eighteen different types of amino acids are present in every $2 \mathrm{~g}$ of leaf powder. The main objective of this research is to exploit the benefit the of chromium metal capturing ability of the several amino acids present in the untreated moringa leaf powder.

\section{Materials and Methods}

Analytical grade potassium dichromate salt was obtained from Sigma-Aldrich. Stock solutions of different concentrations were prepared using distilled water. The moringa leaf powder was obtained from Organic India ${ }^{\mathrm{TM}}$ and the volume surface mean diameter of the absorbent was found to be 190 microns approximately (from sieve analysis). The main acids present in the moringa leaves include glutamic acid, aspartic acid, ascorbic acid, lysine, methionine, proline, tyrosine and valine [31]. Different amounts of the adsorbent $(0.5,1.0$, $1.5,2.0$ and $2.5 \mathrm{~g})$ with different amount of the initial concentration of the metal $(5,10,15$, $20,40,60,80,100 \mathrm{ppm}$ ) in the solution were used in the experiments. Experiments were conducted for $90 \mathrm{~min}$ by placing the bottles containing the adsorbent and $\mathrm{Cr}$ solution on a shaker that is operated at $100 \mathrm{rpm}$. Temperature was recorded as $24^{\circ} \mathrm{C}$. The concentrations of the $\mathrm{Cr}(\mathrm{VI})$ in the solution at different times were obtained by taking samples and analyzing using a DR5000 spectrophotometer manufactured by HACH Company. A dilution factor of up to 30 was used to meet the concentrations of the solution amenable 
for spectrophotometer analysis. The concentrations obtained from the diluted samples were compared with the original standard solutions. Further, replicate experiments were performed for the dosage of $1 \mathrm{~g}$ of the adsorbent with 5, 10,15 and $20 \mathrm{ppm} \mathrm{Cr}(\mathrm{VI})$ solutions and the corresponding standard deviation for the concentration was obtained. The $\mathrm{pH}$ and temperature during the experiments were measured using the $\mathrm{pH}$ meter supplied by Extech Instruments Company. The characterization of different group vibrations was done by conducting FTIR analysis [32,33]. The docking of the metals to the amino acids was simulated and analyzed by using AutoDock Vina package and the visualization or post-processing was performed by using Visual Molecular Dynamics (VMD) package. More details on the molecular docking are explained in Section 3.2.

\section{Results and Discussion}

The high proportion of amino acids with pendent carboxylate and also ascorbic acid with pendent hydroxyl groups has a significant effect on the coordination of $\mathrm{Cr}(\mathrm{VI})$. Compared to an amine group, the carboxylate group has more tendency to capture the $\mathrm{Cr}(\mathrm{VI})$ as the former would sterically hinder or block the access to the main chain. The carboxylate group on these amino acids exercises the chelating or bridging action by forming complexes with the $\mathrm{Cr}(\mathrm{VI})$ which is attributed to the stretching of the $\mathrm{C}=\mathrm{O}$ as shown in the FTIR analysis (see Figure 1). Figure 2 shows the FTIR analysis for the moringa powder alone and chromium solution alone with replicates. The vertical shift between the replicates is due to the slight variation in the place holder for the sample within the FTIR instrument. Otherwise, both replicates overlap with each other in Figure 2. In Figures 1 and 2, the peak at $3750 \mathrm{~cm}^{-1}$ corresponds to the $\mathrm{N}-\mathrm{H}$ bonds, the strong broad band at about $3330 \mathrm{~cm}^{-1}$ is due to the $\mathrm{O}-\mathrm{H}$ stretch (which changes before and after uptake of $\mathrm{Cr}(\mathrm{VI}))$ and the band at about $1550 \mathrm{~cm}^{-1}$ relates to the coordinated carboxylate with the metal ion. The change in the proportions of the $3330 \mathrm{~cm}^{-1}$ and $1550 \mathrm{~cm}^{-1}$ peaks relative to that of the raw moringa can be attributed to the capture of the $\mathrm{Cr}(\mathrm{VI})$. Additionally, the peak at $2850 \mathrm{~cm}^{-1}$ corresponds to the aliphatic $\mathrm{C}-\mathrm{H}$ (the peak shifts due to the uptake of $\mathrm{Cr}(\mathrm{VI})$ ). From the FTIR analysis, it showed that the contribution from the chelating effect due to the $\mathrm{O}-\mathrm{H}$ groups present in the ascorbic acid dominate over the corresponding contribution from the carboxylate groups in the amino acids. All these observations are in complete agreement with the findings reported by Gupta and Balomajumber [32] where they have used water hyacinth as the biosorbent to remove chromium and phenol simultaneously. The absorption of the $\mathrm{Cr}(\mathrm{VI})$ on to the acidic sites of the biosorbent is also confirmed by measuring the $\mathrm{pH}$ during experiments. The chromium in the solution has the possibility of existing as the chromate ion $\left(\mathrm{CrO}_{4}^{2-}\right)$ or in the hydrogenated form $\left(\mathrm{HCrO}_{4}^{-}\right)$based on the acid dissociation kinetics given by Equations (1) and (2) [33,34].

$$
\begin{aligned}
\mathrm{H}_{2} \mathrm{CrO}_{4} & \leftrightarrow \mathrm{H}^{+}+\mathrm{HCrO}_{4}^{-} \quad k_{1}=10^{-0.9} \\
\mathrm{HCrO}_{4}^{-} & \leftrightarrow \mathrm{H}^{+}+\mathrm{CrO}_{4}^{2-} \quad k_{2}=10^{-6.5}
\end{aligned}
$$

The $\mathrm{pH}$ of the solution in all experiments varied between 4.8 and 6.2 which corresponds to slightly acidic medium. Figure 3 shows the variation of $\mathrm{pH}$ for the adsorption experiment corresponding to a loading of $2 \mathrm{~g}$ and for different concentrations $(40,60,80$ and $100 \mathrm{ppm}$ ) of the chromium with respect to time. Similar trends were observed for lower concentrations of chromium (5, 10, 15 and $20 \mathrm{ppm}) . \mathrm{Cr}(\mathrm{VI})$ is a good oxidizer of organic compounds (involving radicals) in acidic medium [35,36]. Al Abadleh et al. have explained qualitatively and quantitatively the tendency of the surface-bound carboxylate to bind and control the interaction of chromium ions in silica-water interfaces [37]. The presence of a significant number of carboxylates and hydroxyl groups in the moringa leaf powder (which is a biosorbent rather than synthesized chemical) has shown the same phenomenon of adsorption of $\mathrm{Cr}(\mathrm{VI})$ ions. 


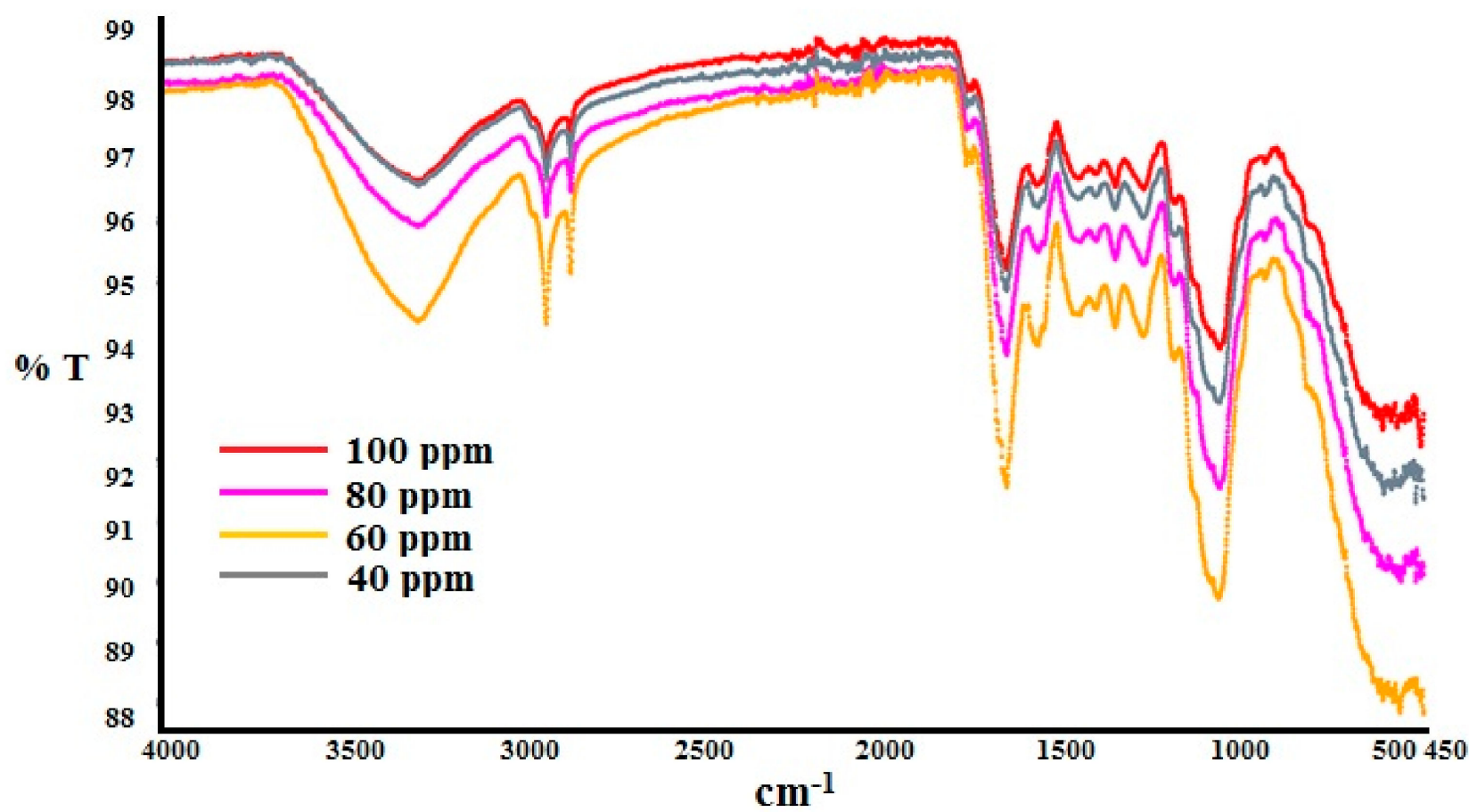

Figure 1. FTIR analysis of sample corresponding to $2 \mathrm{~g}$ of adsorbent and for different concentrations of the chromium solution.

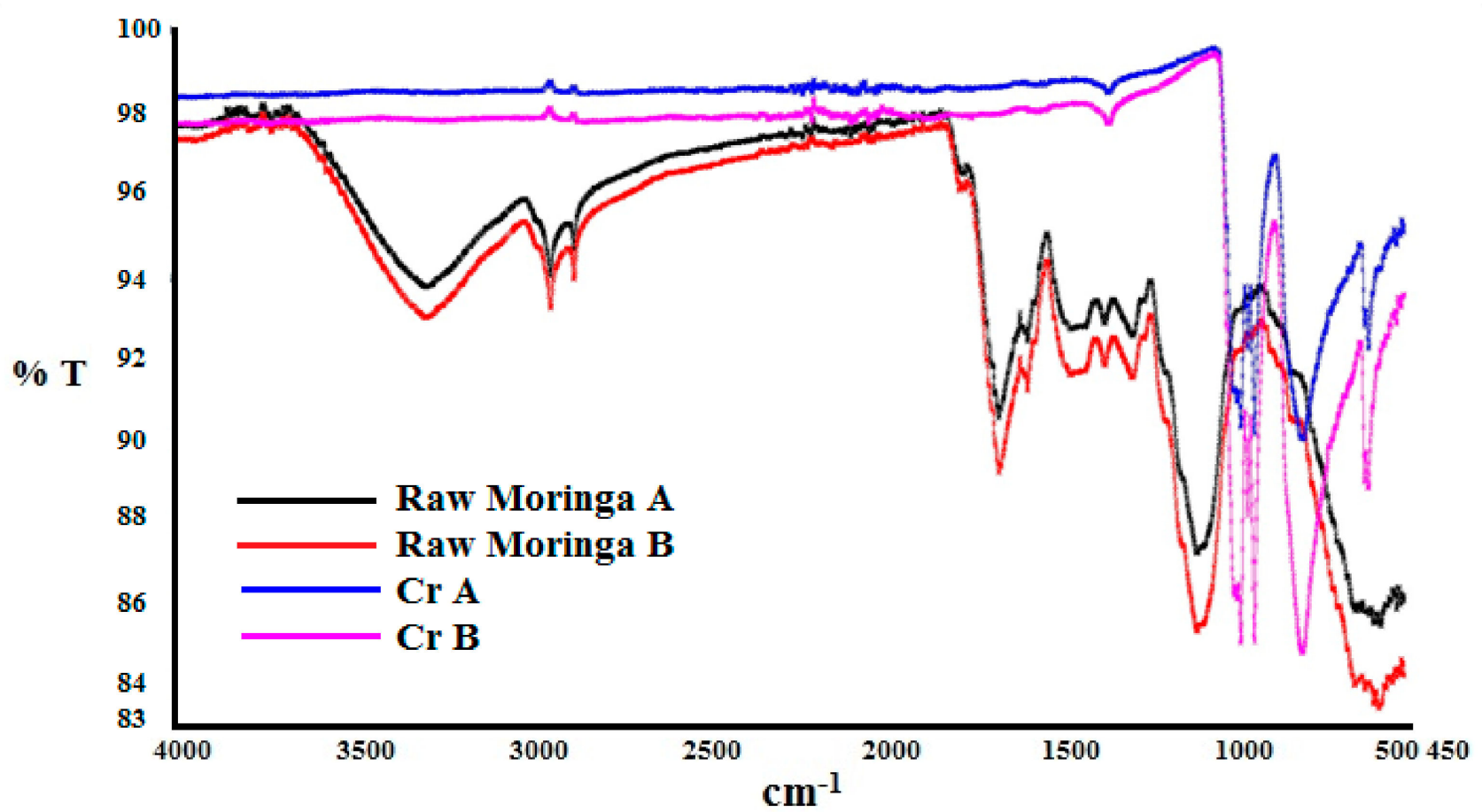

Figure 2. FTIR analysis of moringa powder alone and chromium solution alone (A, B are replicates). 


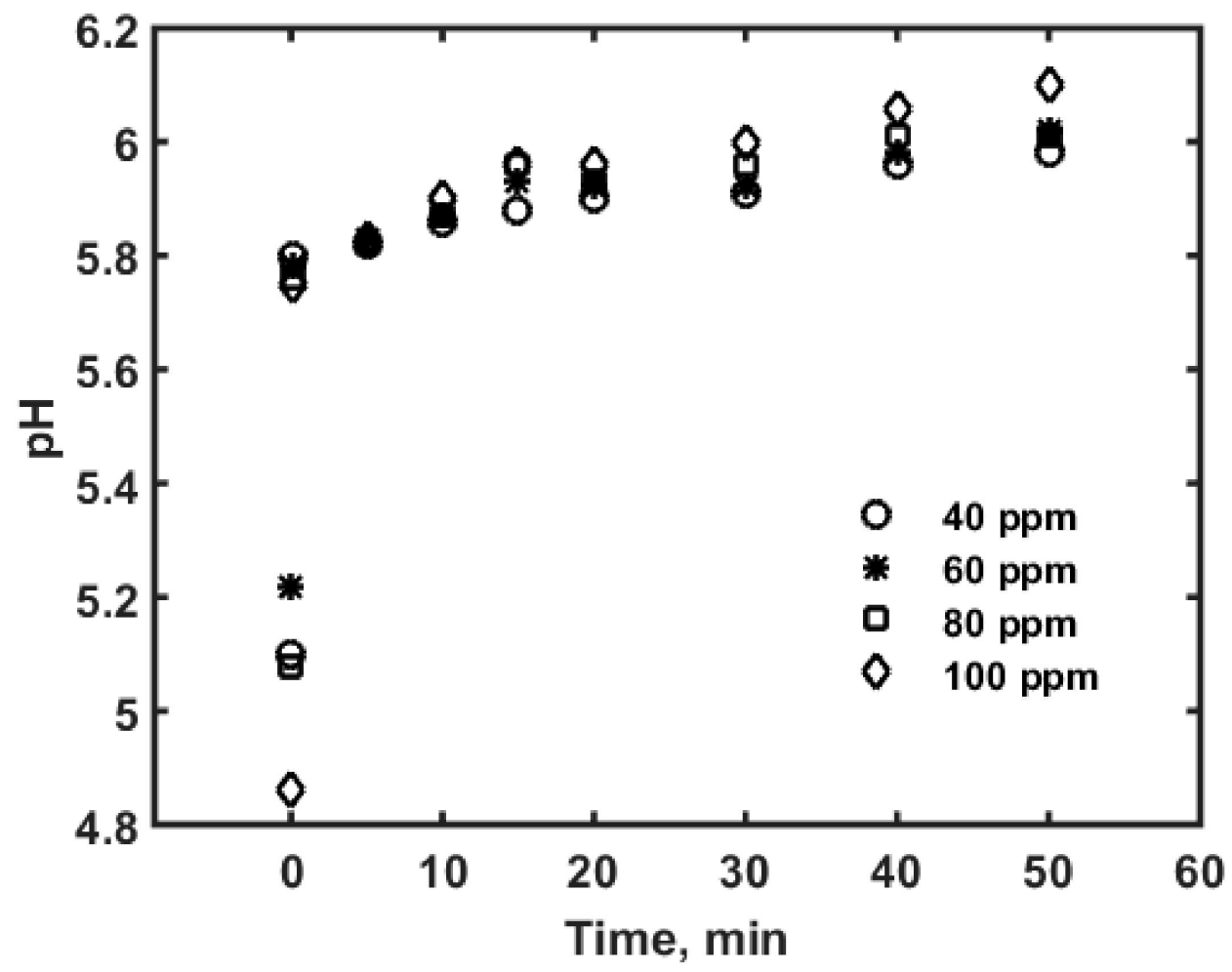

Figure 3. Variation of $\mathrm{pH}$ (with an accuracy of $+0.01 \mathrm{pH}$ ) with respect to time with $2 \mathrm{~g}$ biosorbent and different $\mathrm{Cr}(\mathrm{VI})$ concentrations.

Figure $4 \mathrm{a}$,b shows the $\mathrm{Cr}(\mathrm{VI})$ concentration profile with respect to time for an initial concentration of 5 to $20 \mathrm{ppm}$ and 40 to $60 \mathrm{ppm}$, respectively, for an adsorbent dosage of $2 \mathrm{~g}$. From the sharp decrease in the concentration within the first half hour, it appears that the removal of $\mathrm{Cr}(\mathrm{VI})$ is caused by adsorption only.
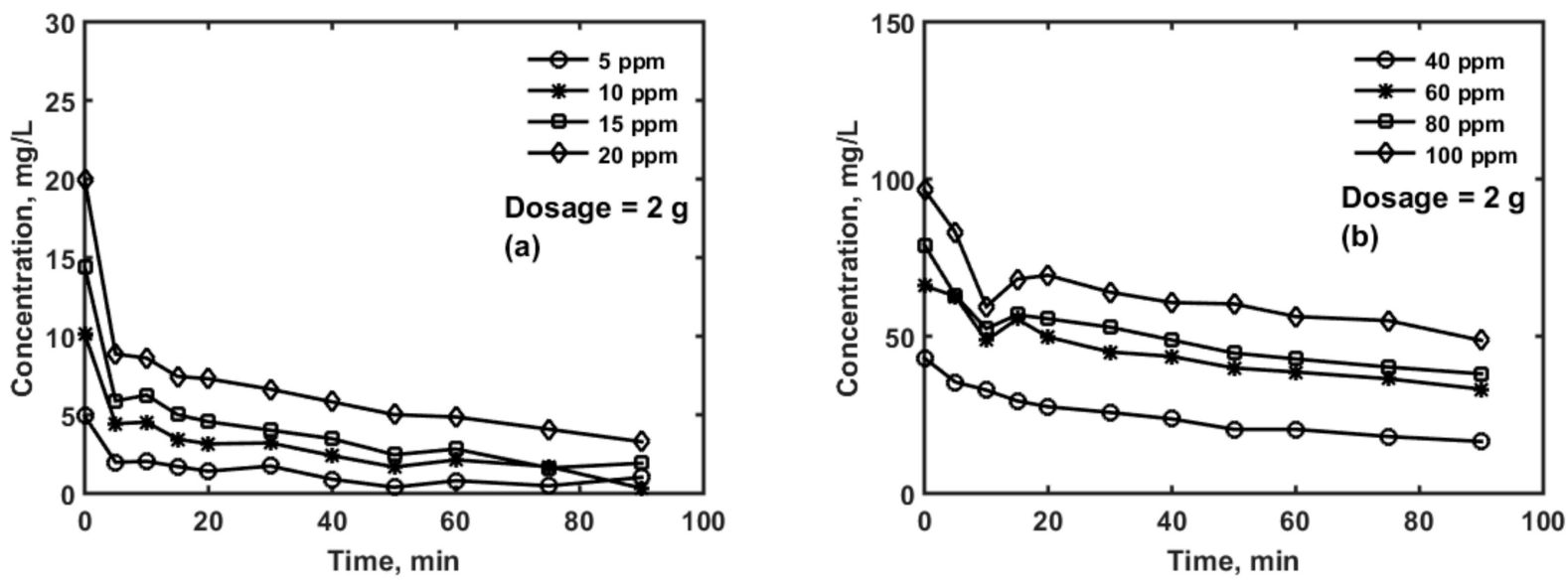

Figure 4. Concentration profiles for an adsorbent dosage of $2 \mathrm{~g}$ for an initial metal concentration of (a) 5 to $20 \mathrm{ppm}$ and (b) 40 to $100 \mathrm{ppm}$. The standard deviation for the concentration in these figures is $0.06 \mathrm{mg} / \mathrm{L}$.

From Figure $4 \mathrm{a}, \mathrm{b}$, it can be seen that a significant degree of adsorption takes place using the moringa as the absorbent for different initial concentration of $\mathrm{Cr}(\mathrm{VI})$. Steady state is reached within one and a half hours. This trend was also observed for other dosages of moringa powder $(0.5,1$ and $2.5 \mathrm{~g})$. 


\subsection{Adsorption Isotherms and Kinetics Modelling}

The results obtained from the adsorption experiments for different initial concentrations of the $\mathrm{Cr}(\mathrm{VI})$ and different dosages of the sorbent (moringa powder) are modelled using Langmiur [38], Freundlich [39] and Redlich-Peterson [40] isotherms. The model equations for these isotherms are given by Equations (3)-(5).

Langmiur isotherm:

$$
q_{e}=q_{m} \frac{k_{L} C_{e}}{1+k_{L} C_{e}}
$$

Freundlich isotherm:

$$
q_{e}=k_{F} C_{e}^{1 / n}
$$

Redlich-Peterson isotherm:

$$
q_{e}=\frac{k_{R P} C_{e}}{1+\alpha_{R P} C_{e}^{\beta}}
$$

where $q_{e}(\mathrm{mg} / \mathrm{g})$ and $C_{e}(\mathrm{mg} / \mathrm{L})$ are the $\mathrm{Cr}(\mathrm{VI})$ concentration at equilibrium in the sorbent and in solution, respectively. The constants $\left[k_{L}, q_{m}\right],\left[k_{F}, n\right]$ and $\left[k_{R P}, \alpha_{R P}, \beta\right]$ are the parameters corresponding to the Langmiur, Freundlich and Redlich-Peterson isotherms, respectively. The values obtained for these parameters (with $99 \%$ confidence intervals) by fitting the experimental data using a nonlinear least square fit (in MATLAB) are shown in Table 1.

Table 1. Parameter values obtained for different isotherms.

\begin{tabular}{cccc}
\hline Parameter & Values & \multicolumn{2}{c}{$\mathbf{9 9 \%}$ Confidence Interval } \\
\hline$k_{L}$ & 0.0535 & 0.0316 & 0.0753 \\
\hline$q_{m}$ & 2.8293 & 2.4015 & 3.2570 \\
\hline$k_{F}$ & 0.3029 & 0.2271 & 0.3787 \\
\hline$n$ & 2.0368 & 1.7546 & 2.3190 \\
\hline$k_{R P}$ & 0.5907 & 0.0000 & 1.8929 \\
\hline$\alpha_{R P}$ & 1.2840 & 0.0000 & 5.3536 \\
\hline$\beta$ & 0.5981 & 0.3780 & 0.8181 \\
\hline
\end{tabular}

Figures $5 \mathrm{a}, 6 \mathrm{a}$ and $7 \mathrm{a}$ show the comparison of the experimental values of $C_{e}$ vs. $q_{e}$ with the Langmuir, Freundlich and Redlich-Peterson isotherms, respectively. Figures $5 \mathrm{~b}, 6 \mathrm{~b}$ and $7 \mathrm{~b}$ shows the experimental values vs. predicted values of $q_{e}$ and the corresponding $\mathrm{R}^{2}$ obtained for these isotherms that were used to fit the data. From Figures 5-7, it clearly shows that the experimental data very well fits with all the three isotherms as evidenced from the high $\mathrm{R}^{2}(>0.90)$. Sorption of $\mathrm{Cr}(\mathrm{VI})$ follows all the three isotherms with almost the same degree of $R^{2}$. Using the parameters from the Langmiur isotherm, a dimensionless separation factor $\mathrm{R}_{\mathrm{L}}$ is defined by Equation (6) [41].

$$
R_{L}=\frac{1}{1+k_{L} C_{o}}
$$

where $C_{o}$ is the initial concentration of $\mathrm{Cr}(\mathrm{VI})$. For the current study, $R_{L}$ is obtained to be in the range of 0.157 to 0.789 for $\mathrm{Cr}(\mathrm{VI})$ initial concentrations varying from $100 \mathrm{mg} / \mathrm{L}$ to $5 \mathrm{mg} / \mathrm{L}$. The values of $\mathrm{R}_{\mathrm{L}}$ are indicative of favorable adsorption as they lie between 0 and 1 . 

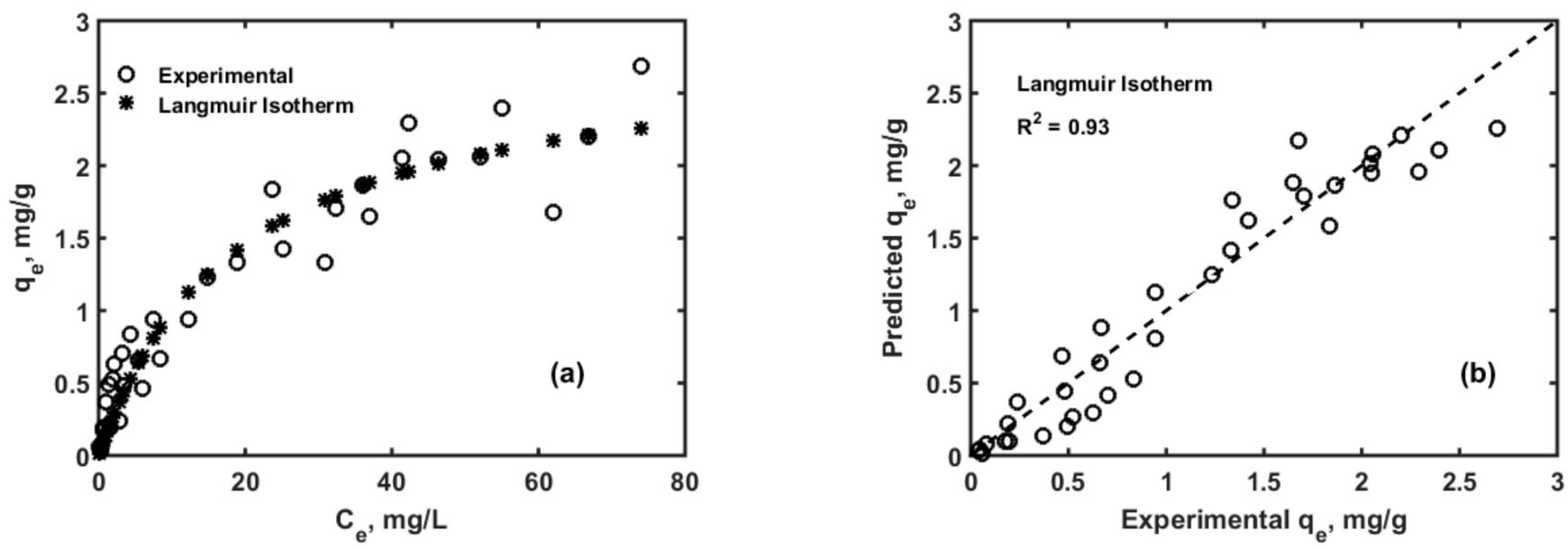

Figure 5. (a) Comparison of $C_{e}$ vs. $q_{e}$ using Langmuir isotherm. (b) Experimental $q_{e}$ vs. predicted $q_{e}$ using Langmuir isotherm.
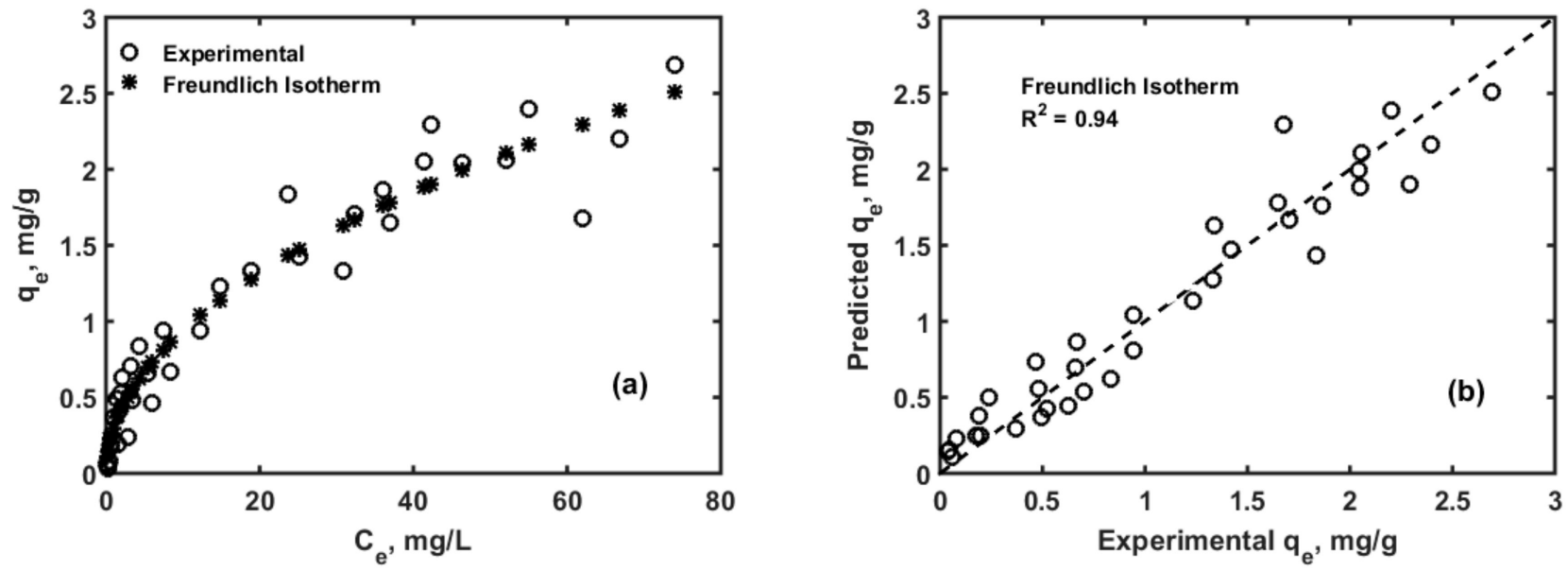

Figure 6. (a) Comparison of $C_{e}$ vs. $q_{e}$ using Freundlich isotherm. (b) Experimental $q_{e}$ vs. predicted $q_{e}$ using Freundlich isotherm.
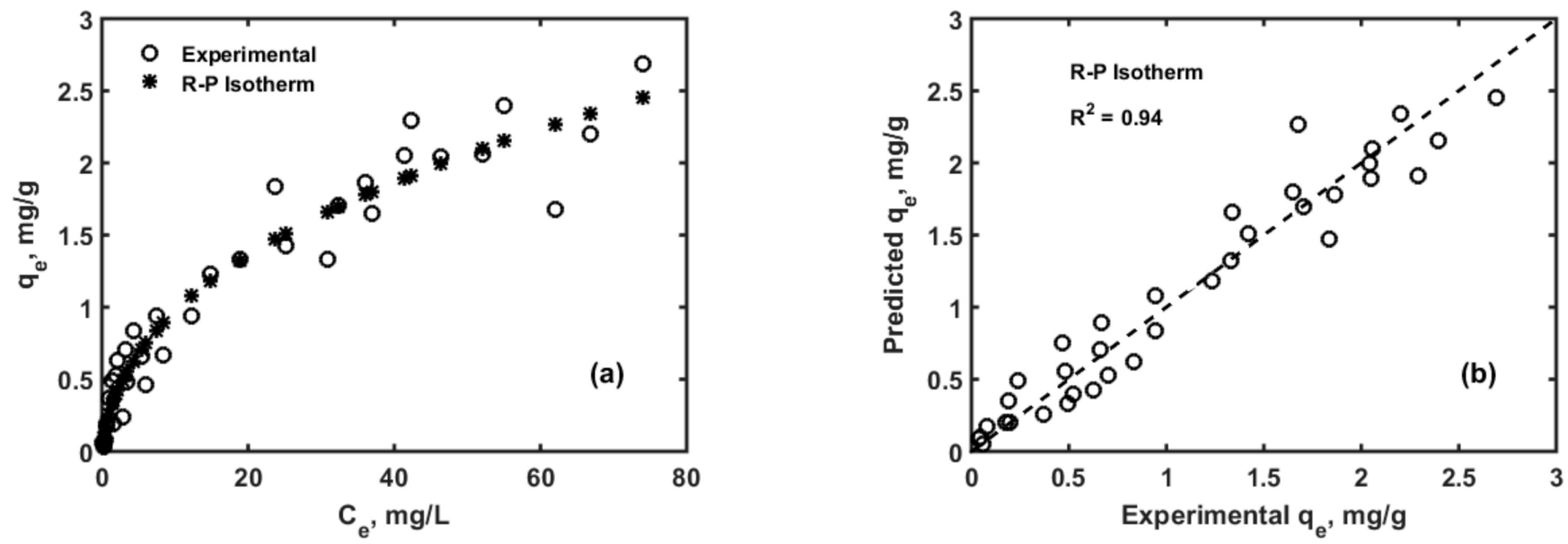

Figure 7. (a) Comparison of $C_{e}$ vs. $q_{e}$ using Redlich-Peterson (R-P) isotherm. (b) Experimental $q_{e}$ vs. predicted $q_{e}$ using Redlich-Peterson isotherm. 
Further kinetic models were fit to the experimental results to study the solute uptake rate. Two common models are used to describe the solid/liquid adsorption. The pseudo-first-order model [42] and the pseudo-second-order model [43] are fitted with the experimental results for all different initial dosages of the absorbent. Equations (7) and (8) describe the pseudo-first-order model and the pseudo-second-order models.

$$
\begin{gathered}
\log \left(q_{t}-q_{e}\right)=\log \left(q_{e}\right)-\frac{k_{1}}{2.303} t \\
\frac{t}{q_{t}}=\frac{1}{k_{2} q_{e}^{2}}+\frac{t}{q_{e}}
\end{gathered}
$$

where $q_{t}$ is the amount of $\mathrm{Cr}(\mathrm{VI})$ at any time $t, q_{e}$ is the corresponding equilibrium value, $k_{1}$ $\left(\mathrm{min}^{-1}\right)$ and $k_{2}\left(\mathrm{~g} \mathrm{mg}^{-1} \mathrm{~min}^{-1}\right)$ are equilibrium rate constants for the pseudo-first-order and the pseudo-second-order models, respectively. Figure $8 \mathrm{a}, \mathrm{b}$ shows the comparison of the experimental $q_{t}$ vs. $t$ with the corresponding fitted pseudo-first-order and the pseudosecond-order models for a dosage of $1 \mathrm{~g}$ and with an initial $\mathrm{Cr}(\mathrm{VI})$ concentration of $40 \mathrm{ppm}$. It was observed that the pseudo-second-order model fits very well compared to the pseudofirst-order model which is evident from the $\mathrm{R}^{2}$ values. This was true for other dosage and other initial concentrations of $\mathrm{Cr}(\mathrm{VI})$. Hence, the adsorption of $\mathrm{Cr}(\mathrm{VI})$ onto the moringa leaf powder follows the pseudo-second-order kinetics.
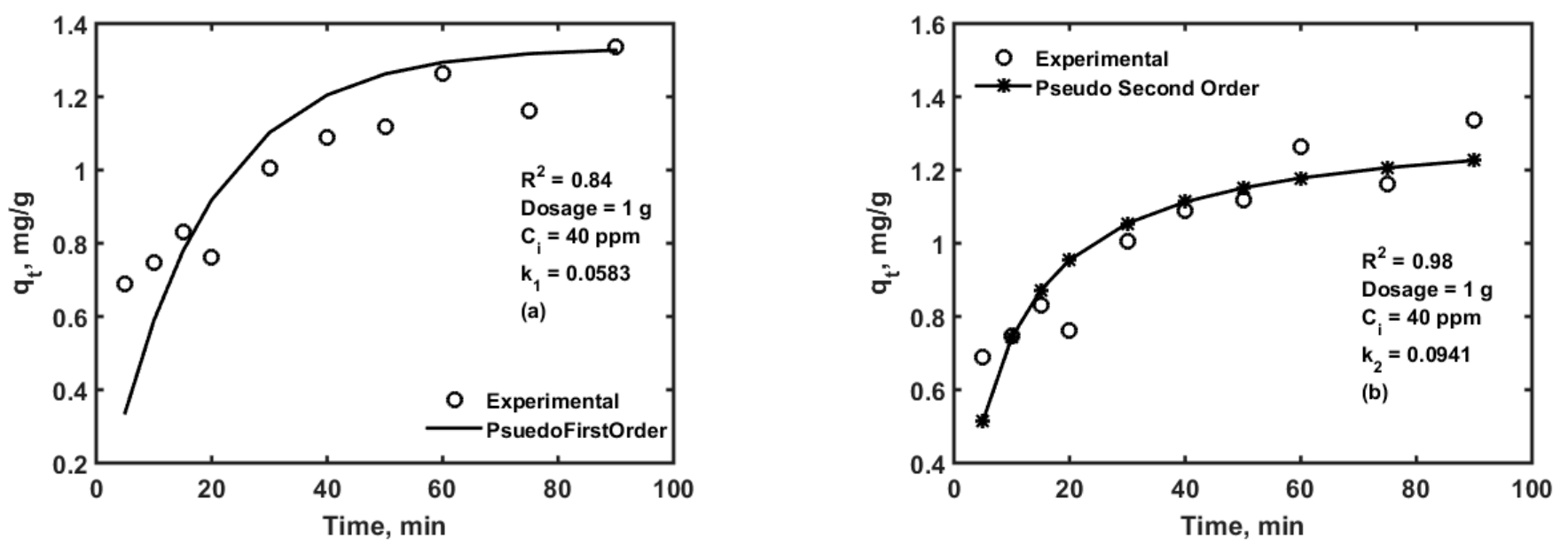

Figure 8. Comparison of experimental $q_{t}$ vs. $t$ with those obtained using (a) pseudo-first-order model and (b) pseudosecond-order model.

From Figure 9, it is clear that as the initial concentration of $\mathrm{Cr}(\mathrm{VI})$ in the solution increases, the removal efficiency decreases for all different dosages of the absorbent. This is in agreement with the trends observed with other absorbents used for not only removal of $\mathrm{Cr}(\mathrm{VI})$ but also for other heavy metals [35,36]. With respect to the effect of amount of dosage, the removal efficiency increased with an increase in the amount of dosage. Removal efficiencies of over $90 \%$ were achieved for metal concentrations of less than $20 \mathrm{ppm}$ and an absorbent dosage of $2 \mathrm{~g}$. A major benefit and also difference in using the proposed untreated (meaning chemically not modified) moringa leaf powder is that the removal efficiency of this absorbent is very high even at very low levels of initial metal concentrations (see Figure 9 for initial concentrations less than 20 ppm). Usually, adsorption is preferred to other methods of separations for higher levels of initial concentration of the metals.

The removal efficiency which indirectly is related to the amount of $\mathrm{Cr}(\mathrm{VI})$ adsorbed on the absorbent using different dosages of the absorbent with different initial conditions is shown in Figure 9. 


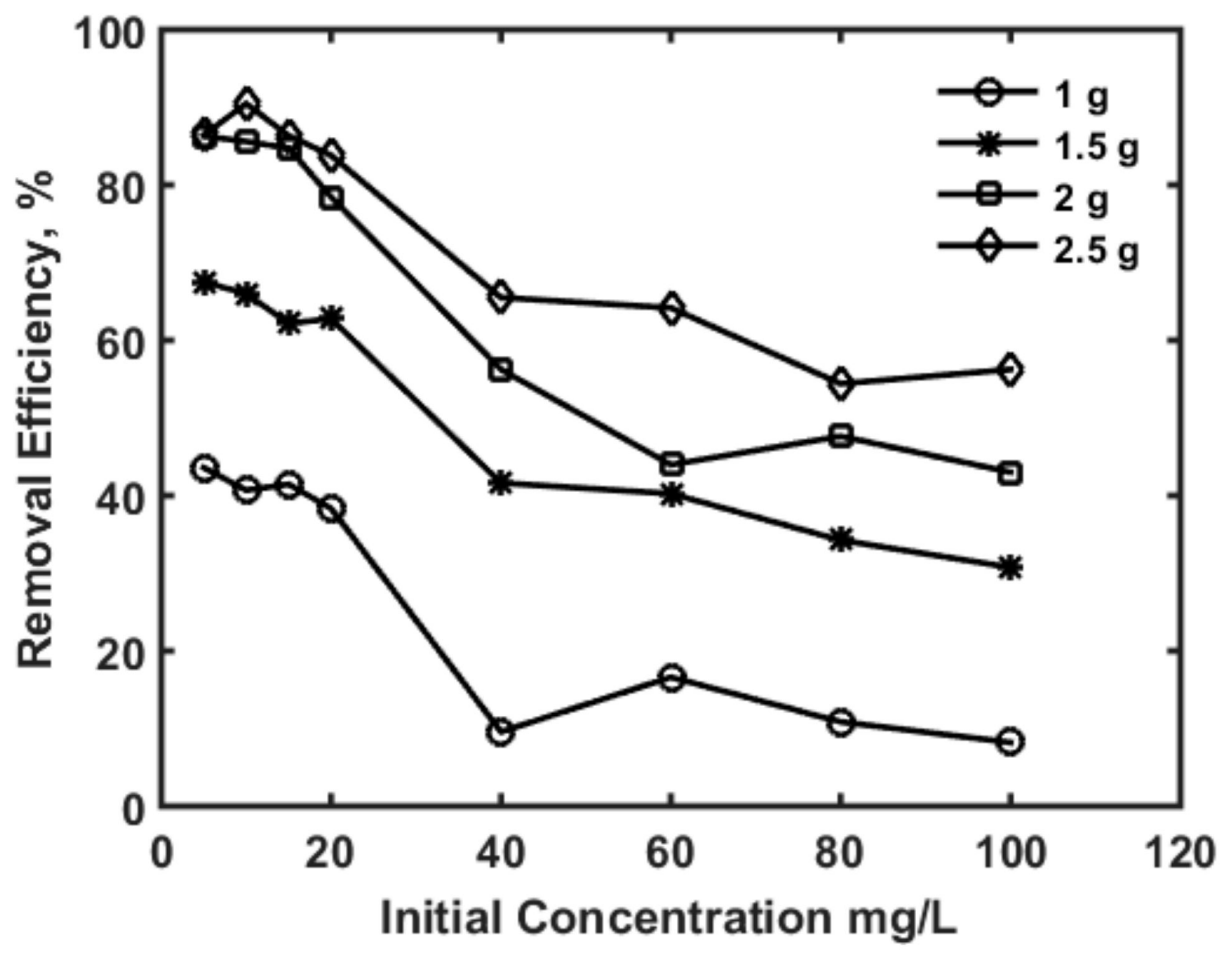

Figure 9. $\mathrm{Cr}(\mathrm{VI})$ removal efficiency for different initial concentrations of the metal and for different dosages of the absorbent.

\subsection{Docking Simulation Results}

Docking of the metal ion with different amino acids and ascorbic acid was simulated using the AutoDock Vina package [44] and the visualization or post-processing was completed using the Visual Molecular Dynamics (VMD) package [45]. Non-bonded interaction forces such as electrostatic and van der Waals mainly influence the docking between the metal ion and the major acids present in moringa leaves. The protein data bank (PDB) structure files for these acids were retrieved from the Protein Data Bank [46]. The acids that were used in the docking simulations include valine (VAL), tyrosine (TYR), proline (PRO), methionine (MET), lysine (LYS), glutamic acid (GLU), aspartic acid (ASP) and ascorbic acid (ASC). Since $\mathrm{Cr}(\mathrm{VI})$ was not available in the AutoDock Vina package, manganese, which has a similar molecular weight and with charge of $\mathrm{Cr}(\mathrm{VI})$, was chosen for conducting the docking simulations. The charge of the metal, hexavalent chromium ion or $\mathrm{Cr}(\mathrm{VI})$ was preserved in the simulation and the ion to be docked on the different amino acids and ascorbic acid was referred to as $\mathrm{Z}$ ion. The preparation of the structural files to be ran on AutoDock Vina were completed using AutoDock tools [47].

Table 2 shows the docking score obtained for the $\mathrm{Z}$ ion (which is similar to $\mathrm{Cr}(\mathrm{VI})$ ) with respect to different locations within the major acids present in the moringa leaves. The docking scores obtained in Table 2 show that ascorbic acid has more potential (with a maximum docking score of -0.6$)$ to bind the $\mathrm{Cr}(\mathrm{VI})$ compared to other amino acids. This is due to the presence of two hydroxyl groups close to each other in the ascorbic acid compared to a single hydroxyl group located in one of the amino acids, such as tyrosine. Among the amino acids, glutamic and aspartic acids have exhibited a second-highest docking score of -0.5 which is attributed to the fact that they have two carboxyl groups contributing to higher potential for the capture of the metal compared to lysine, methionine, proline, tyrosine and valine. The docking scores were also obtained for the position of the metal to be between the amino group and the double bonded oxygen atom in the carboxyl group as shown in Figure 10a-d. The corresponding docking score was observed to be -0.4 . The docking score for a sole amino group without a carboxyl group neighbor was found to be very small, thus leading to the smallest binding tendency of the metal. 
Table 2. Docking of different amino acids and ascorbic acid present in the moringa leaves.

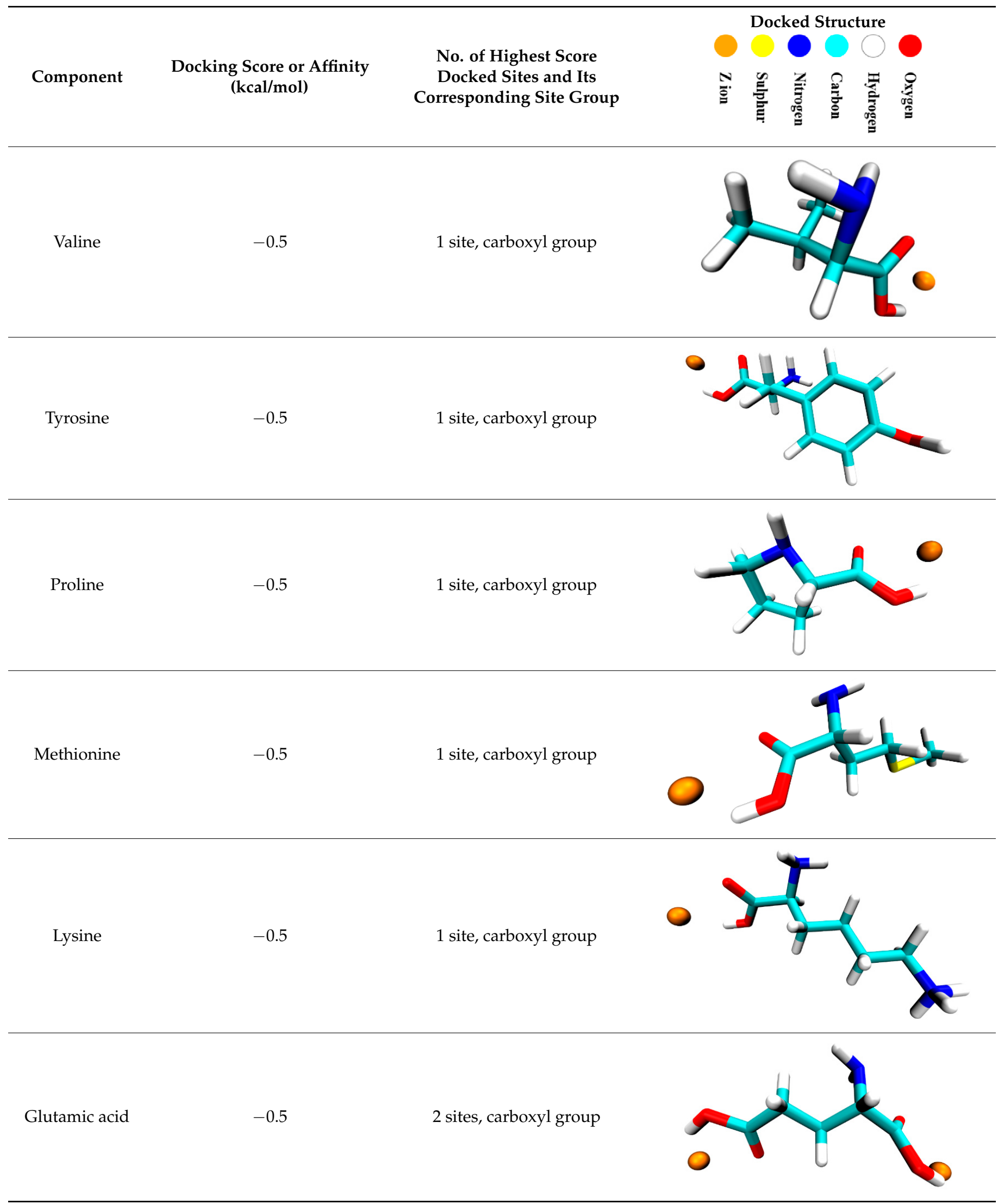


Table 2. Cont

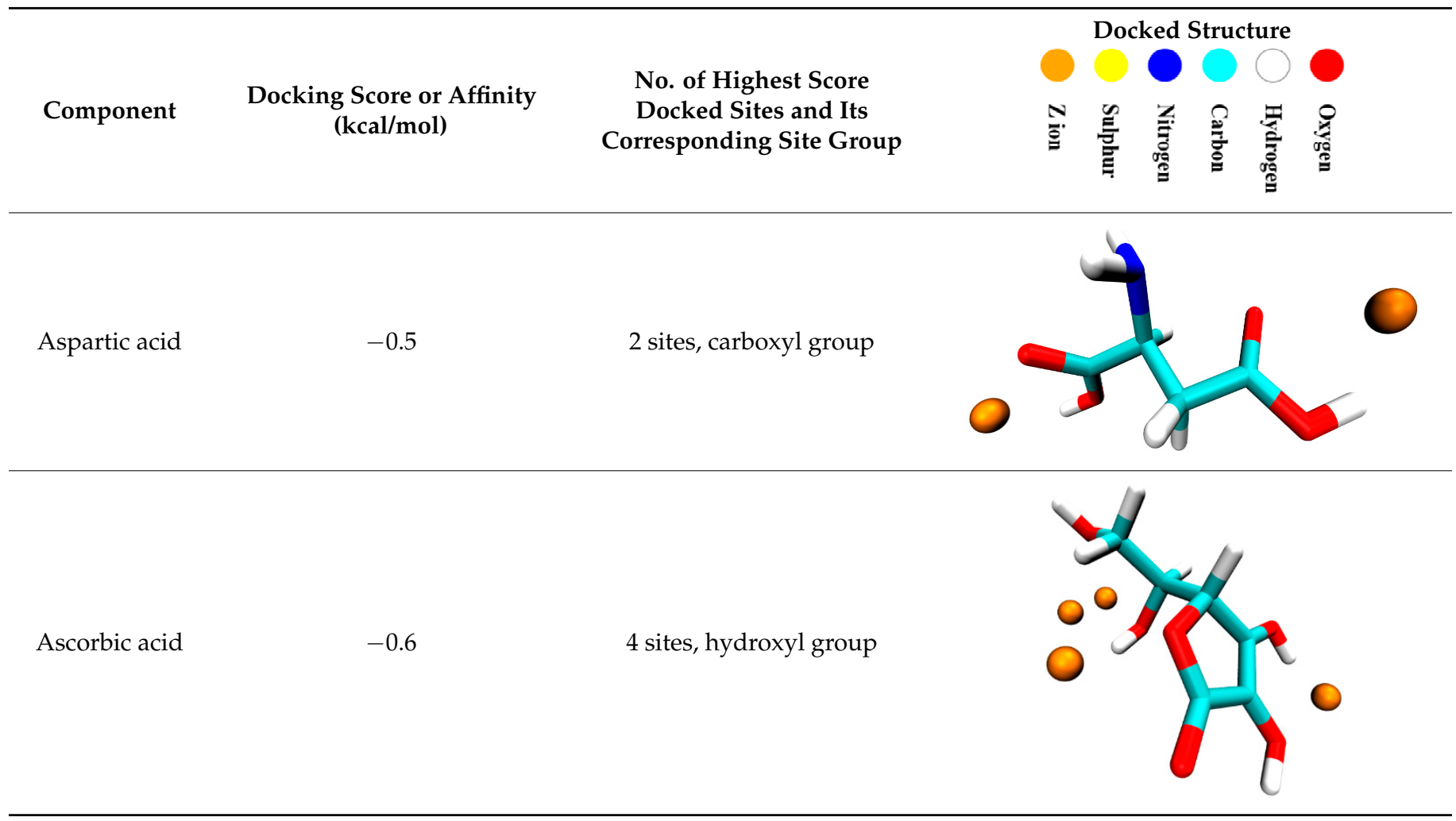

(a)

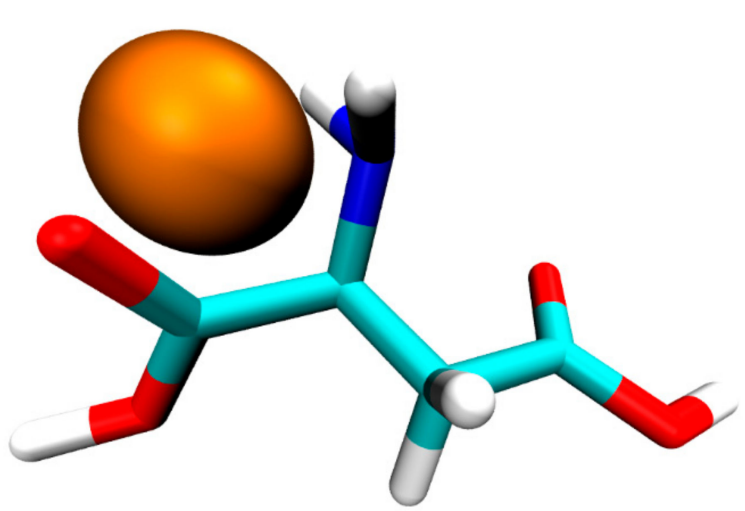

(c)

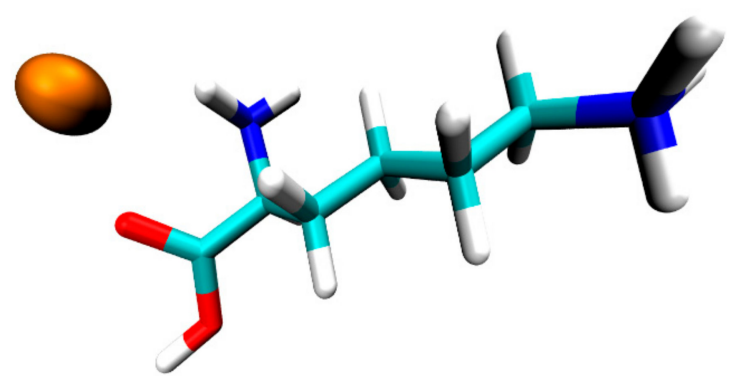

(b)

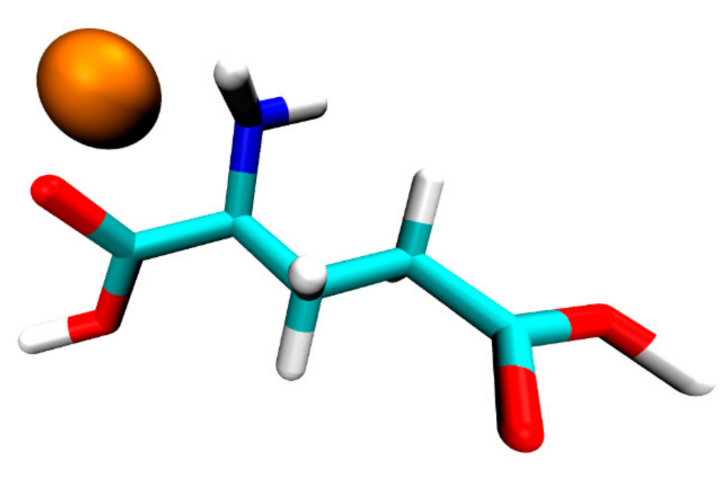

(d)

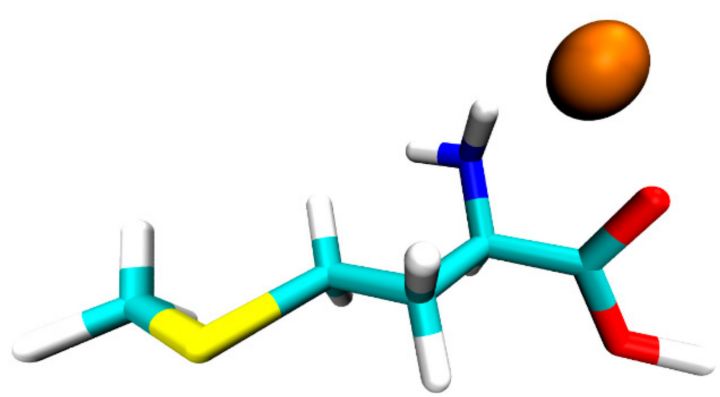

Figure 10. Z ion docked with amino group in (a) aspartic acid, (b) glutamic acid, (c) lysine, (d) methionine. 
On the other hand, the docking score with respect to the carboxyl group in ascorbic acid was found to be -0.5 . Further, with the hydroxyl groups there were two situations with respect to the distance between them. Within the structure of the ascorbic acid, when the distance between the hydroxyl groups was large, the docking score was observed to be -0.5 but when the hydroxyl groups were nearer, then the docking score was found to be -0.6 (suggesting a greater binding of the metal). From the docking simulation results it was found that ascorbic acid has the highest overall docking scores with four sites of -0.6 and two sites of -0.5 followed by the carboxyl groups of the other amino acids. These findings are in complete agreement with the experimental results explained in the FTIR analysis (see Figures 1 and 2 and the discussion in Section 3). The chelating effect of ascorbic acid in the reduction of hexavalent chromium was also reported by Xe et al. [48]. Hence, the untreated moringa with a significant amount of ascorbic acid and amino acids is one of the best biosorbents that can be used to remove $\mathrm{Cr}(\mathrm{VI})$ efficiently from aqueous solutions.

\section{Conclusions}

Untreated green moringa leaf powder was efficiently used to remove toxic hexavalent chromium from aqueous solution. It was found that $\mathrm{Cr}(\mathrm{VI})$ removal efficiency above $90 \%$ was achieved with short adsorption times (around 60 to $80 \mathrm{~min}$ ). Different dosages of this absorbent were used to treat solutions with different initial concentration of the heavy metal. A biosorbent dosage of $2.5 \mathrm{~g}$ led to giving maximum $\mathrm{Cr}(\mathrm{VI})$ removal efficiency for an initial metal concentration range of 5 to $100 \mathrm{mg} / \mathrm{L}$. It was observed that the adsorption of $\mathrm{Cr}(\mathrm{VI})$ on this biosorbent very well followed Langmiur, Fruendlich and Redlich-Peterson isotherms. The kinetics study showed that it follows a pseudo-second-order model. The metal removal efficiency was strongly affected with the initial concentration of the metal in the solution. Higher removal efficiency was observed at lower levels of initial metal concentration in the solution. The metal docking preferences in the different acids (present in moringa leaves) were realized by performing simulations using the AutoDock Vina package. The simulation results confirmed that the carboxyl groups in the amino acids and hydroxyl groups in the ascorbic acid are the major sources of binding sites for $\mathrm{Cr}(\mathrm{VI})$. Further, the absorbent used in this study forms a suitable case not only for removal of the $\mathrm{Cr}(\mathrm{VI})$ at lower levels but also can be used for pre-treatment of higher initial concentration solution. Untreated green moringa leaf powder used as a biosorbent in this study leads to a sustainable and cheaper option for treating wastewater containing $\mathrm{Cr}(\mathrm{VI})$.

Author Contributions: Conceptualization, methodology and modeling the data, C.M.R.M.; design of experiments and performing of experiments, A.T. and Z.A.; Molecular docking, S.Q.F., writing, supervision and project administration, C.M.R.M. and A.E. All authors have read and agreed to the published version of the manuscript.

Funding: This research received no external funding.

Acknowledgments: The authors would like to extend their gratitude to Abu Dhabi University for supporting this research.

Conflicts of Interest: The authors declare no conflict of interest.

\section{References}

1. Singh, K.; Renu, N.; Agarwal, M. Methodologies for Removal of Heavy Metal Ions from Wastewater: An Overview. Interdi. Engironm. Rev. 2017, 18, 124-142. [CrossRef]

2. Cheng, G.; Li, X. Bioreduction of Chromium (VI) By Bacillus Sp. Isolated from Soils of Iron Mineral Area. Eur. J. Soil Biol. 2009, 45, 483-487. [CrossRef]

3. Zhao, Y.; Shen, H.; Pan, S.; Hu, M. Synthesis, Characterization and Properties of Ethylenediamine-Functionalized $\mathrm{Fe}_{3} \mathrm{O}_{4} \mathrm{Magnetic}$ Polymers for Removal of Cr (VI) In Wastewater. J. Hazard Mater. 2010, 182, 295-302. [CrossRef] [PubMed]

4. Kinuthia, G.K.; Ngure, V.; Beti, D.; Lugalia, R.; Wangila, A.; Kamau, L. Levels of heavy metals in wastewater and soil samples from open drainage channels in Nairobi, Kenya: Community health implication. Sci Rep. 2020, 10, 8434. [CrossRef] [PubMed]

5. Golbaz, S.; Jafari, A.; Rafiee, M.; Kalantary, R. Separate and Simultaneous Removal of Phenol, Chromium, and Cyanide from Aqueous Solution by Coagulation/Precipitation: Mechanisms and Theory. Chem. Eng. J. 2014, 253, 251-257. [CrossRef] 
6. Dittert, I.; de Lima Brandão, H.; Pina, F.; da Silva, E.; de Souza, S.; de Souza, A.; Botelho, C.; Boaventura, R.; Vilar, V. Integrated Reduction/Oxidation Reactions And Sorption Processes For Cr(VI) Removal From Aqueous Solutions Using Laminaria Digitata Macro-Algae. Chem. Eng. J. 2014, 237, 443-454. [CrossRef]

7. Gładysz-Płaska, A.; Majdan, M.; Pikus, S.; Sternik, D. Simultaneous Adsorption of Chromium (VI) and Phenol on Natural Red Clay Modified By HDTMA. Chem. Eng. J. 2012, 179, 140-150. [CrossRef]

8. Cavaco, S.; Fernandes, S.; Quina, M.; Ferreira, L. Removal of Chromium from Electroplating Industry Effluents by Ion Exchange Resins. J. Hazard Mater. 2007, 144, 634-638. [CrossRef]

9. Lin, L.; Xu, X.; Papelis, C.; Cath, T.; Xu, P. Sorption of Metals and Metalloids from Reverse Osmosis Concentrate on Drinking Water Treatment Solids. Sep. Purif. Technol. 2014, 134, 37-45. [CrossRef]

10. Hamdan, S.; El-Naas, M. Characterization of the Removal of Chromium (VI) from Groundwater by Electrocoagulation. J. Ind. Eng. Chem. 2014, 20, 2775-2781. [CrossRef]

11. Sun, Y.; Yue, Q.; Mao, Y.; Gao, B.; Gao, Y.; Huang, L. Enhanced Adsorption of Chromium onto Activated Carbon by MicrowaveAssisted H3PO4 Mixed with Fe/ Al/Mn Activation. J. Hazard Mater. 2014, 265, 191-200. [CrossRef] [PubMed]

12. Pehlivan, E.; Cetin, S. Sorption of Cr (VI) Ions on Two Lewatit-Anion Exchange Resins and Their Quantitative Determination Using UV-Visible Spectrophotometer. J. Hazard Mater. 2009, 163, 448-453. [CrossRef] [PubMed]

13. Fang, J.; Gu, Z.; Gang, D.; Liu, C.; Ilton, E.; Deng, B. Cr (VI) Removal from Aqueous Solution by Activated Carbon Coated with Quaternized Poly(4-Vinylpyridine). Environ. Sci. Technol. 2007, 41, 4748-4753. [CrossRef] [PubMed]

14. Sankararamakrishnan, N.; Jaiswal, M.; Verma, N. Composite Nanofloral Clusters of Carbon Nanotubes and Activated Alumina: An Efficient Sorbent For Heavy Metal Removal. Chem. Eng. J. 2014, 235, 1-9. [CrossRef]

15. Guo, J.; Li, Y.; Dai, R.; Lan, Y. Rapid Reduction of Cr(VI) Coupling with Efficient Removal of Total Chromium in the Coexistence of $\mathrm{Zn}(0)$ and Silica Gel. J. Hazard Mater. 2012, 243, 265-271. [CrossRef]

16. Fathy, N.; El-Wakeel, S.; Abd El-Latif, R. Biosorption and Desorption Studies on Chromium(VI) by Novel Biosorbents of Raw Rutin And Rutin Resin. J. Environ. Chem. Eng. 2015, 3, 1137-1145. [CrossRef]

17. Gautam, R.; Mudhoo, A.; Lofrano, G.; Chattopadhyaya, M. Biomass-Derived Biosorbents for Metal Ions Sequestration: Adsorbent Modification and Activation Methods and Adsorbent Regeneration. J. Environ. Chem. Eng. 2014, 2, 239-259. [CrossRef]

18. Zhang, Z.; Liao, M.; Zeng, H.; Xu, S.; Liu, X.; Du, J.; Zhu, P.; Huang, Q. Temperature Effect On Chromium(VI) Removal By Mg/Al Mixed Metal Oxides As Adsorbents. Appl. Clay Sci. 2014, 102, 246-253. [CrossRef]

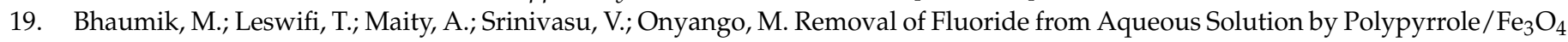
Magnetic Nanocomposite. J. Hazard Mater. 2011, 186, 150-159. [CrossRef]

20. Yogeshwaran, V.; Priya, A.K. Removal of Hexavalent Chromium by Adsorption Using Natural Wastes-A Review. Adv. Recycl. Waste Manag. 2017, 2, 1000141.

21. AL-Othman, Z.; Ali, R.; Naushad, M. Hexavalent Chromium Removal from Aqueous Medium by Activated Carbon Prepared From Peanut Shell: Adsorption Kinetics, Equilibrium and Thermodynamic Studies. Chem. Eng. J. 2012, 184, 238-247. [CrossRef]

22. ALOthman, Z.; Naushad, M.; Ali, R. Kinetic, Equilibrium Isotherm and Thermodynamic Studies of Cr(VI) Adsorption Onto Low-Cost Adsorbent Developed from Peanut Shell Activated with Phosphoric Acid. Environ. Sci. Pollut. R 2013, 20, 3351-3365. [CrossRef]

23. Xin, H.; Ke-hong, L.; Qi, L.; Ju, Q.; Wang, J.; Zhu, H. Superfine grinding affects physicochemical, thermal and structural properties of Moringa Oleifera leaf powders. Ind. Crops Prod. 2020, 151, 112472.

24. Cuellar-Nuñez, M.L.; Luzardo-Ocampo, I.; Campos-Vega, R.; Gallegos-Corona, M.A.; González de Mejía, E.; Loarca-Piña, G. Physicochemical and nutraceutical properties of moringa (Moringa oleifera) leaves and their effects in an in vivo AOM/DSSinduced colorectal carcinogenesis model. Food Res. Int. 2018, 105, 159-168. [CrossRef] [PubMed]

25. Naik, G.; Priyadarsini, K.; Satav, J.; Banavalikar, M.; Sohoni, D.; Biyani, M.; Mohan, H. Comparative Antioxidant Activity Of Individual Herbal Components Used In Ayurvedic Medicine. Phytochemistry 2003, 63, 97-104. [CrossRef]

26. Naznin, A.; Mamunur, R.; Amran, M. Comparison of Leaves Extract with Atenolol on Serum Triglyceride, Serum Cholesterol, Blood Glucose, Heart Weight, Body Weight in Adrenaline Induced Rats. Saudi J. Biol. Sci. 2008, 15, $253-258$.

27. Reddy, D.; Ramana, D.; Seshaiah, K.; Reddy, A. Biosorption Of Ni(II) from Aqueous Phase by Moringa Oleifera Bark, a Low Cost Biosorbent. Desalination 2011, 268, 150-157. [CrossRef]

28. Alves, V.; Coelho, N. Selective Extraction And Preconcentration Of Chromium Using Moringa Oleifera Husks As Biosorbent And Flame Atomic Absorption Spectrometry. Microchem. J. 2013, 109, 16-22. [CrossRef]

29. Obuseng, V.; Nareetsile, F.; Kwaambwa, H. A Study Of The Removal Of Heavy Metals From Aqueous Solutions By Moringa Oleifera Seeds And Amine-Based Ligand 1,4-Bis[N,N-Bis(2-Picoyl)Amino]Butane. Anal. Chim. Acta 2012, 730, 87-92. [CrossRef] [PubMed]

30. Reddy, D.; Harinath, Y.; Seshaiah, K.; Reddy, A. Biosorption Of Pb(II) From Aqueous Solutions Using Chemically Modified Moringa Oleifera Tree Leaves. Chem. Eng. J. 2010, 162, 626-634. [CrossRef]

31. Aja, P.; Nwachukwu, N.; Ibiam, U.; Igwenyi, I.; Offor, C.; Orji, U. Chemical Constituents of Moringa Oleifera Leaves and Seeds From Abakaliki, Nigeria. Am. J. Phytomedicine Clin. Ther. 2014, 3, 310-321.

32. Gupta, A.; Balomajumder, C. Removal of $\mathrm{Cr}(\mathrm{VI})$ and Phenol Using Water Hyacinth from Single and Binary Solution in the Artificial Photosynthesis Chamber. J. Water Process. Eng. 2015, 7, 74-82. [CrossRef] 
33. Venditti, F.; Cuomo, F.; Ceglie, A.; Ambrosone, L.; Lopez, F. Effects of Sulfate Ions and Slightly Acidic Ph Conditions on Cr(VI) Adsorption onto Silica Gelatin Composite. J. Hazard Mater. 2010, 173, 552-557. [CrossRef] [PubMed]

34. Saha, B.; Gill, R.; Bailey, D.; Kabay, N.; Arda, M. Sorption of Cr(VI) From Aqueous Solution by Amberlite XAD-7 Resin Impregnated with Aliquat 336. React. Funct. Poly. 2004, 60, 223-244. [CrossRef]

35. Ege, S. Organic Chemistry: Structure and ReactiVity, 4th ed.; Houghton Mifflin Co.: Boston, MA, USA, 1999.

36. Kulkarni, R.; Bilehal, D.; Nandibewoor, S. Oxidation of Isoniazid by Quinolinium Dichromate in an Aqueous Acid Medium and Kinetic Determination of Isoniazid in Pure and Pharmaceutical Formulations. Anal. Sci. 2004, 20, 743-747. [CrossRef]

37. Al-Abadleh, H.; Mifflin, A.; Bertin, P.; Nguyen, S.; Geiger, F. Control of Carboxylic Acid and Ester Groups on Chromium (VI) Binding to Functionalized Silica/Water Interfaces Studied by Second Harmonic Generation. J. Phys. Chem. B 2005, 109, 9691-9702. [CrossRef] [PubMed]

38. Langmuir, I. The Constitution and Fundamental Properties of Solids and Liquids. J. Am. Chem. Soc. 1916, 38, 2221-2295. [CrossRef]

39. Freundlich, H. Über Die Adsorption in Lösungen. Z. Für. Phys. Chem. 1906, 57, 385-470. [CrossRef]

40. Redlich, O.; Peterson, D. A Useful Adsorption Isotherm. J. Phys Chem. 1959, 63, 1024. [CrossRef]

41. Weber, T.; Chakravorti, R. Pore And Solid Diffusion Models For Fixed-Bed Adsorbers. AIChE J. 1974, 20, 228-238. [CrossRef]

42. Lagergren, S. Zur Theorie Der Sogenannten Adsorption Gelöster Stoffe. K. Sven. Vetensk. Handl. 1898, $24,1-39$.

43. Ho, Y. Second-Order Kinetic Model for the Sorption of Cadmium onto Tree Fern: A Comparison of Linear and Non-Linear Methods. Water Res. 2006, 40, 119-125. [CrossRef]

44. Trott, O.; Olson, A. Autodock Vina: Improving the Speed and Accuracy of Docking with A New Scoring Function, Efficient Optimization, and Multithreading. J. Comput. Chem. 2010, 31, 455-461. [CrossRef]

45. Humphrey, W.; Dalke, A.; Schulten, K. VMD: Visual Molecular Dynamics. J. Mol. Graph. 1996, 14, 33-38. [CrossRef]

46. RCSB PDB. Available online: https:/ / www.rcsb.org (accessed on 1 July 2020).

47. Morris, G.; Huey, R.; Lindstrom, W.; Sanner, M.; Belew, R.; Goodsell, D.; Olson, A. Autodock4 And Autodocktools4: Automated Docking with Selective Receptor Flexibility. J. Comput. Chem. 2009, 30, 2785-2791. [CrossRef]

48. Xu, X.; Li, H.; Li, X.; Gu, J. Reduction of Hexavalent Chromium by Ascorbic Acid In Aqueous Solutions. Chemosphere 2004, 57, 609-613. [CrossRef] [PubMed] 